\title{
Mediating Effect of Service Quality on the Relationship Between Customer Relationship Management and Satisfaction of Commercial Banks' Account Holders In Nairobi City County, Kenya
}

\author{
Rael N. Mwirigi \\ Department of Business Administration \\ Faculty of Business Studies, Chuka University, P. O. Box 109-60400, Chuka, Kenya
}

\begin{abstract}
The objective of this study was to establish the mediating effect of service quality on the relationship between CRM and satisfaction of commercial banks account holders in Nairobi City County, Kenya. The study adopted a cross-sectional research design involving descriptive and explanatory research techniques. The target population was $34,649,583$ account holders out of which a sample of 400 respondents was selected using mixed sampling techniques. Data was collected using a semi structured questionnaire and analyzed using both descriptive and inferential statistics. Simple and multiple linear regression were conducted to assess the relationships between the variables. The study was limited to a few constructs, cross sectional data, localized population and self reporting. The study established that service quality had a statistically significant mediating effect on the relationship between CRM and satisfaction of commercial banks account holders. The study recommends that commercial banks management should consider service quality dimensions when developing strategies because they have a significant effect on account holder satisfaction with commercial banking services. Commercial banks in Kenya and the central bank can use the findings of this study to formulate CRM related policies that enhance service quality and satisfaction of account holders. To increase the level of generalizability and objectivity, future studies should be carried out in microfinance banks, Savings and Credit Organizations using additional variables and a different methodology.
\end{abstract}

Keywords: Customer relationship management, Service quality, Account holder satisfaction, Commercial banks DOI: $10.7176 / \mathrm{EJBM} / 11-9-07$

Publication date:March $31^{\text {st }} 2019$

\subsection{INTRODUCTION}

Globally, banks are faced with a highly competitive environment as they progress from product and sales focused practices to a marketing orientation where competition is based on customer centred strategies that enhance customer satisfaction. The banking environment has also undergone a major transformation caused by the changes in regulatory reforms and technological advancement that has escalated the level of competition (Roy \& Shekar, 2011;Godson, 2009). The advancements in technology have also increased customer awareness and demand for quality banking services. To maintain lifetime relationships with customers, commercial banks have adopted customer relationship management (CRM) practices (Sin, Tse \& Yim, 2005;Godson). These practices enable banks to enhance quality service delivery and the resultant customer satisfaction (Chan \& Ahmad, 2013). In addition, banks' investment in CRM increases profitability, competitiveness and market share (Narver \& Slater, 1990; Ul Haq, Rammay, Urehman \& Jam, 2010). Banking is a customer centred service where CRM, customer satisfaction and service quality have become essential differentiating factors in the competitive financial environment (Sadek \& Tantawi, 2009). Hence the financial services industry in Kenya is experiencing challenges such as achieving financial targets and satisfying their customer base. These developments have made the banking sector more competitive as banks strive to meet customer demands through development of Customer Relationship Management (CRM) strategies and service quality initiatives that aim at customer satisfaction (KPMG, 2013).

\subsection{Customer relationship management}

Parvatiyar and Sheth (2002) assert that CRM is a strategy and a process of acquiring, retaining and partnering with customers in order to create superior value for both parties. Similarly, Thakur, Summey and Balasubramanian (2006) posit that CRM involves elements of marketing, sales, services, operations and information technology (IT) which aim at understanding the behaviour and needs of customers. As a business strategy, CRM incorporates processes, functions and networks that deliver value to customers at a profit. It also helps firms to acquire new customers, satisfy and retain them so as to maximize their lifetime value. It involves identification and interaction with customers, differentiation and customization of products and services. It also focuses on customers' satisfaction through transformation of the organizational structure, processes, culture and technology (Peppers, Rogers \& Dorf, 1999). As a multidisciplinary concept, CRM incorporates other disciplines such as marketing including relationship marketing and consumer behaviour. It also involves management and information 
technology such as e-commerce and human computer interaction. According to Sin et al., (2005) CRM is a multidimensional concept consisting of four broad components namely; key customer focus, CRM organization, knowledge based CRM and technology based CRM. Key customer focus involves customer centred decisions that take into account the welfare, needs and interests of customers. Customer driven organizations provide quality products and services that meet customer expectations and thus satisfying them more than competitors (Kotler \& Armstrong, 2004).

\subsection{Service Quality}

Gronroos (2002) describes service quality as the perceived judgments resulting from an evaluation process where customers compare their expectations with what they perceive to have received. Service quality is also conceptualized as a multifaceted construct comprising five dimensions. These dimensions are: Responsiveness, Assurance, Tangibility, Empathy and Reliability (RATER); (Buttle 1996; Parasuraman, Berry \& Zeithaml, 1988; Cronin \& Taylor, 1992). Tangibility refers to physical facilities, employees and equipment used by the service provider (Sureschander, Rajendran \& Kamalanabhan, 2002). Reliability reflects the dependability of the service provider and accuracy of performance while responsiveness means the employees' ability to act promptly and their readiness to help customers (Buttle, 1996). Assurance refers to the knowledge, courtesy and confidence of employees while empathy is the ability to provide caring and individualized attention to the customers (Robledo, 2001).

In addition Zeithaml, Bitner and Gremler (2006), describe service quality as the general judgmental attitude in connection with the overall excellence of superiority of the service. In contrast, Sultan and Wong (2010) conceptualize service quality as an attitude emanating from customers' long term assessment of services received. However, the current study adopted the five dimensions of service quality namely; responsiveness, assurance, tangibility, empathy and reliability as postulated by Parasuraman, Berry and Zeithaml (1988) in examining the mediating role of service quality on the relationship between CRM and customer satisfaction in commercial banks.

\subsection{Customer Satisfaction}

Hansemark and Abinson (2004) assert that satisfaction is an overall customer attitude arising from the differences between service providers' performance and perceived quality expectations regarding the fulfillment of needs, goals and desires. This contrasts with Battisti and Salini (2011) who describe customer satisfaction as a latent variable that cannot be observed but is transaction specific, while service quality reflects a long term attitude that is more enduring. The debate on the relationship between service quality and customer satisfaction has been advanced by scholars over the years. However, the concepts are distinct but related in nature. Service quality models assume that consumers come into a service encounter with prior expectations which is matched with an actual service encounter to determine service quality. The customer is satisfied if the service experience meets the expected service. Hence high quality services increase customer satisfaction (Parasuraman, Berry \& Zeithaml, 1985). According to Sahieh (2006), service quality precedes customer satisfaction that is associated with one transaction at a time as well as the emotional reaction to a product or service encounter. It is the outcome achieved when service or product benefits meet the customer's expectations (Kotler \& Keller, 2006). Giese and Cote (2000) and Fornell (1992) view satisfaction as an overall evaluation of the customer's experience with a product or service. Further, Howard and Sheth (1996) describe customer satisfaction as a psychological condition that results when disconfirmed expectations are compared with the consumer's feelings about their consumption experience. It is also a judgmental attitude that depends on a specific consumption. The debate on the relationship between service quality and customer satisfaction has been advanced by scholars over the years. However, the concepts are distinct but related in nature. The service quality models assume that consumers come into a service encounter with prior expectations which is matched with an actual service encounter to determine the service quality. The customer is satisfied if the service experience meets the expected service. Hence high quality services increase customer satisfaction (Parasuraman, Berry \& Zeithaml, 1985). According to Sahieh (2006), service quality precedes customer satisfaction that is associated with one transaction at a time as well as the emotional reaction to a product or service encounter. In the current study, customer satisfaction is described as the overall assessment of a customer's experience after a service encounter with a commercial bank and the study proposed that CRM affects account holder satisfaction with commercial banking services. The study used a modified version of hierarchical customer satisfaction measures developed by Mihelis et al., (1998). These measures are positive experience with banks' personnel, preference for banks' products and services, the image of the bank and access to banking services.

\subsection{Objective of the study}

The objective of this study was to establish the mediating effect of service quality on the relationship between customer relationship management and satisfaction of commercial banks' account holders in Nairobi City County, Kenya. 


\subsection{REVIEW OF RELATED LITERATURE}

\subsection{Theoretical Review}

\subsubsection{Service Quality Model (Gaps Model)}

The theoretical background of service quality originates from the studies carried out by Juran and Deming in 1950s. These were the original studies on measurement in manufacturing plants that resulted to the study of service quality (Deming, 1986). Parasuraman et al., (1988) further developed the gaps model explaining the gaps that may arise between what the customer expects to receive and what the organization provides. Service quality is described as the gap between customer perception and expectations. Customer perception is what the customer thinks of the service provided while customer expectations refer to the service the customer anticipates to receive. The discrepancy between the customer perception of the service received and their expectations result in gaps or unmet expectations (Parasuraman et al,.1988).

Gap one occurs as a result of management's misunderstanding of customers' service quality expectation which arise from inadequate market research, limited vertical communication and bureaucracy. Gap two arises from management understanding correctly customer needs and wants but failing to set specified performance standards according to customer expectations. This creates a gap between service specification and service delivery. The third gap is the conformance gap that arises when employees fail to perform the services as stipulated by the service provider. The employees may lack the required skills or they may be unwilling to meet performance standards.

The fourth gap is the communication gap that occurs due to the wrong information passed to the customer by service providers' employees. In the banking scenario, customers may not be informed about activities carried out in the back office and delays may be interpreted as failure. The bank customer understanding may also be affected by the image of the bank and its advertisements. Gap five is the difference between customer expectations of a service and their perception of the service provided. The customer expectations are determined by individual needs, word of mouth communication and past service encounter (Parasuramann et al., 1988).

The service quality (SERVQUAL) models assert that when customer expectations are greater than perception of service quality the customer will experience some level of dissatisfaction. When service expectations are less than perception of service, service quality will be more than satisfactory. However, if the expected service is equal to perceived service then the result is customer satisfaction which is the ultimate goal of offering quality services. Service quality also enhances profitable long term relationships between customers and service providers. In the context of this study, service quality was measured in terms of reliability, assurance, tangibility, empathy and responsiveness (Parasuraman et al., 1988).

According to the gaps model, customers expected service is a product of verbal communication, personal needs and past experience while perceived service is a function of service delivery and external communication. Critiques of this theory such as Gronroos (1982) and Letinen (1982) were of the view that SERVQUAL fails to account for image, functional and technical dimensions of service quality. Similarly, Carman (1990) proposes that the model has a scale of more than five elements and should be customized to a specific service. However, Aldridge and Rowley (1998) argue that SERVQUAL model is the most widely used instrument in assessing service quality. This study used the SERVQUAL scale to assess service quality of commercial banks as perceived by account holders. This model was considered important in this study because it influences the relationship between CRM variables and satisfaction of account holders.

\subsection{Customer Relationship Management, Service Quality and Customer Satisfaction}

The successful implementation of CRM is affected by the company's quality of service delivery. Service quality is an assessment of what customers perceive about their service encounter. The expectations-performance gap was elaborated by Parasuraman et al, (1988) who studied various US industries and developed the SERVQUAL model. This model quantified the service expectation-perception into five dimensions namely; tangibility, empathy, reliability, assurance and responsiveness. The model assert that when customer expectations are greater than perception of service quality the customer will experience some level of dissatisfaction. However, if the expected service is equal to perceived service then the result is customer satisfaction. According to the gaps model, customers expected service is a product of verbal communication, personal needs and past experience while perceived service is a function of service delivery and external communication (Buttle 1996; Parasuraman, Berry \& Zeithaml, 1988; Cronin \& Taylor, 1992).

Many studies relating to the mediating effect service quality have been conducted in different business sectors and environments. Rostami, Mohammadi and Yousepoor (2014) assessed the relationship between CRM and customer satisfaction in Ghavamin Bank in Iran. The variables examined were service quality, service characteristics, level of access and complaint handling. The results revealed that the four CRM factors have a positive effect on customer satisfaction.

Roy (2014) carried out a study on factors influencing CRM practice in selected commercial banks in India. 
The study variables were communication, customer belief, knowledge ability of employees, efficiency of banking services and employee attitude (independent variables); CRM was used as a moderating variable while service quality was a dependent variable. The study established that communication, customer belief, knowledge ability of employees, efficiency of banking services and employee attitude significantly affected CRM and service quality. The study used service quality as a moderating variable while the current study used it as an independent variable.

Fasih and Khan (2014) assessed the effect of service quality on customer satisfaction and loyalty in the Pakistani banking sector. The study aimed at determining the satisfaction level of bank customers with the quality of the different services provided and their loyalty to their respective banks. The results revealed that all the service quality dimensions; empathy, tangibility, responsiveness, reliability and assurance had a positive and significant effect on customer satisfaction and loyalty. A study by Anatastiadon and Jamal (2009) examined the effect of service quality on customer satisfaction and loyalty among bank customers in Greece. The study also assessed the indirect and direct effect of expertise on customer loyalty. The study revealed that reliability, tangibility and empathy are positively related to customer satisfaction which in turn is positively related to loyalty. A study by Kheng (2010), assessed the mediating effect of customer satisfaction on the relationship between service quality and customer loyalty among bank customers Malaysia. The study established that customer satisfaction had a mediating effect on the relationship between service quality dimensions and customer loyalty.

Al-Azzam and Fattah (2015) in their study on the effect of service quality dimensions on customer satisfaction among Arab bank customers in Jordan, indicated that all the five dimensions of service quality have a positive effect on customer satisfaction. The findings support prior studies by Kheng, (2010) and Murugiah and Akgam (2015) who found a positive relationship between customer satisfaction and the five dimensions of service quality. These studies confirmed that the five dimensions of service quality are an important tool for assessing the quality of services in the banking sector but the mediating effect of service quality on the relationship between CRM and customer satisfaction was not assessed, hence the gap addressed in this study.

\subsection{RESEARCH METHODOLOGY}

\subsection{Research Design}

In line with the positivist approach this study adopted a quantitative approach in examining the relationships between variables and formulated research hypotheses, tested them for their validation and subsequent generalization (Saunders, Lewis \& Thornhill, 2009). This study adopted both descriptive and explanatory research design which was cross-sectional in nature as recommended by Copper and Schindler (2003). Disproportionate stratified random sampling was used to select a sample size of 400 from a population of $34,649,583$ commercial banks account holders. Disproportionate stratified sampling helps to balance the strata size and variability to ensure fair representation of all strata (Gay, 1981; Kothari 2004; Borg \& Gall 1989). A sample size of 400 was determined using Yamane (1967) formula for calculating the sample size from a finite population.

$n=\frac{N}{1+N(e)^{2}}$ Where: $\mathrm{n}$ is the sample size, $\mathrm{N}$ is the population size and; $e$ is the allowed margin of error $=0.05$, hence $n=400$

The study collected primary data from account holders of commercial banks in Nairobi headquarters branches using a semi-structured questionnaire as recommended by Kothari (2004). A five point likert rating scale ranging from "not at all" to "a very large extent" was used (Malhotra, Hall, Shaw \& Oppenhelm, 2002).

\subsection{Data analysis methods and interpretation}

Quantitative data were analyzed using both descriptive and inferential statistics in Statistical Package for Social Sciences (SPSS) version 19. Stepwise multiple linear regression was used to establish the mediating effect of service quality on the relationship between CRM and customer satisfaction. The study adopted the four steps causal path analysis by Baron and Kenny (1986) and the following models were adopted:

Step 1: $C S=\beta_{0}+\beta_{1} C R M+\varepsilon^{\prime}$

Step 2: $S Q=\beta_{0}+\beta_{1} C R M+\varepsilon$

Step 3: $C S=\beta_{0}+\beta_{1} S Q+\varepsilon$

Step 4: $C S=\beta_{0}+\beta_{1} C R M+\beta_{2} S Q+\varepsilon$

Where: $C S=$ Customer Satisfaction, $\beta_{0}=$ Constant, $\beta_{1, \beta 2}=$ Regression coefficients $C R M=$ Composite index $\gg \mathrm{f}$ Customer Relationship Management, $\mathrm{SQ}=$ Composite index of Service Quality, $\varepsilon=$ Error term

The results were interpreted based on the regression coefficient, Analysis of Variance (ANOVA) and the value of $\mathrm{R}^{2}$.

\subsection{RESULTS AND DISCUSSION 4.1Response Rate}

The study collected data from 400 commercial bank account holders, out of which 336 (176 males, 160 females) 
questionnaire copies were found to be suitable for further analysis. This constituted a response rate of $84 \%$. According to Rogelburg and Stanton (2007), a response rate of 35\% - 40\% is appropriate for studies conducted at the organizational level and 50\% for studies done at the individual level using survey design.

\subsection{Descriptive Analysis of the Study Variable}

Table 1 contains a summary of the aggregate mean scores of CRM, service quality and customer satisfaction.

Table 1: Summary of Aggregate Mean Scores

\begin{tabular}{|l|l|l|}
\hline Variables & Aggregate Mean Score & Standard Deviation \\
\hline Service Quality & 3.63 & 0.988 \\
\hline Customer Satisfaction & 3.35 & 1.051 \\
\hline Composite Mean score of CRM & 3.51 & 1.116 \\
\hline
\end{tabular}

Source: Survey Data (2017)

The aggregate mean score for CRM responses was 3.51 and a standard deviation of 1.116 implies that commercial banks' CRM practices were implemented to a moderate extent. The aggregate mean score for service quality was 3.63 with a standard deviation of 0.988 . Hence most of the respondents were happy to a large extent with the quality of services received from their banks. The aggregate mean score for customer satisfaction was 3.35 and a standard deviation of 1.051. This suggests that the respondents were to a moderate extent satisfied with banking services.

4.3 Mediating effect of service quality on the relationship between CRM and customer satisfaction of commercial banks account holders

To determine the mediating effect of service quality on the relationship between CRM and customer satisfaction the study tested the following null hypothesis using stepwise multiple linear regression analysis. The study applied the four steps causal path analysis by Baron and Kenny (1986) to test for mediation effect of service quality on the relationship between CRM and satisfaction of commercial banks account holders.

$\mathrm{Ho}_{1}$ : Service quality has no significant mediating effect on the relationship between CRM and satisfaction of commercial banks' account holders.

In the first step, composite index of CRM variables were regressed to predict customer satisfaction. The results of this step are indicated in Table 2 (a-c).

Table 2 (a) Model Summary

\begin{tabular}{|l|l|l|l|}
\hline $\mathrm{R}$ & $\mathrm{R}^{2}$ & Adjusted $\mathrm{R}^{2}$ & Std. Error of the Estimate \\
\hline .739 & .546 & .545 & .487 \\
\hline
\end{tabular}

Source: Survey Data (2017)

Table 2(b): ANOVA

\begin{tabular}{|l|l|l|l|l|l|}
\hline & Sum of Squares & Df & Mean Square & F & Sig. \\
\hline Regression & 92.969 & 1 & 92.969 & 392.483 & .000 \\
\hline Residual & 77.220 & 326 & .237 & & \\
\hline Total & 170.189 & 327 & & & \\
\hline
\end{tabular}

Source: Survey data (2017)

Table 2 ( c ): Regression Coefficients

\begin{tabular}{|l|l|l|l|l|l|}
\hline & \multicolumn{2}{|l|}{ Unstandardized Coefficients } & Standardized Coefficients & t & Sig. \\
\hline & $\mathrm{B}$ & Std. Error & Beta & & \\
\hline (Constant) & .569 & .143 & & 3.979 & .000 \\
\hline CRM & .793 & .040 & .739 & 19.811 & .000 \\
\hline
\end{tabular}

Source: Survey Data (2017)

The results in Table 2 (a) indicate $\mathrm{R}^{2}$ of 0.546 which means that $54.6 \%$ of variation in customer satisfaction is explained by CRM practices. The results in Table 2(b) indicate an F-static of 392.483 and p-value $=0.000$ $<0.05$. This implies that CRM has a significant effect on satisfaction of account holders in commercial banks. The coefficient results of CRM and customer satisfaction in Table 2 (c) are statistically significant at 5\%; $\beta$ eta $=0.793$ and $\mathrm{p}$-value $=0.000$. The results conclude that CRM has a significant effect on satisfaction of commercial banks' account holders in Kenya. Based on the results in Table 2 (a-c), the following model was formulated:

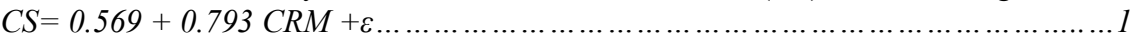

Where: $\mathrm{CS}=$ Composite index of Customer Satisfaction, $\mathrm{CRM}=$ Composite index of Customer Relationship Management, $\varepsilon=$ Error term

In the second step, composite index of CRM was regressed against service quality to predict customer satisfaction. The regression results are presented in Table 3 (a-c). 
Table 3 (a): Model Summary

\begin{tabular}{|l|l|l|l|l|}
\hline Model & R & R Square & Adjusted R Square & Std. Error of the Estimate \\
\hline 1 & $.817^{\mathrm{a}}$ & .668 & .667 & .38640 \\
\hline
\end{tabular}

Source: Survey Data (2017)

Table 3 (b): ANOVA

\begin{tabular}{|l|l|l|l|l|l|l|}
\hline \multicolumn{2}{|l|}{ Model } & Sum of Squares & df & Mean Square & F & Sig. \\
\hline \multirow{3}{*}{1} & Regression & 99.230 & 1 & 99.230 & 664.630 & $.000^{\text {a }}$ \\
\cline { 2 - 7 } & Residual & 49.269 & 330 & .149 & & \\
\cline { 2 - 7 } & Total & 148.499 & 331 & & & \\
\hline \multirow{2}{*}{ P. }
\end{tabular}

a. Predictors: (Constant), CRM

b. Dependent Variable: Service Quality

Source: Survey Data (2017)

Table 3 ( c ): Regression Coefficients

\begin{tabular}{|l|l|l|l|l|l|}
\hline & Unstandardized Coefficients & Standardized Coefficients & t & Sig. \\
\hline & B & Std. Error & Beta & & \\
\hline (Constant) & .763 & .113 & & 6.765 & .000 \\
\hline CRM & .815 & .032 & .817 & 25.78 & .000 \\
\hline
\end{tabular}

Table 3 (a) shows regression results of adjusted $\mathrm{R}^{2}=0.668$ which implies that $66.8 \%$ of the variation in service quality can be explained by CRM and the rest by factors that were not considered in the study. Table 3 (b) presents the analysis of variance results for CRM predicting service quality and indicate an F- statistic of 664.630 with Pvalue $=0.000<0.05$. The results in Table 3 (c) indicate a regression coefficient of 0.815 which means that for every unit increase in CRM, service quality will increase by a factor of 0.815 . In addition, the results indicate that CRM and service quality are statistically significant at $95 \%$ confidence level $(\mathrm{P}=0.000<0.05)$. Based on the findings, the study developed the following model:

$\mathrm{SQ}=0.763+0.815 \mathrm{CRM}+\varepsilon \quad$ Where; $\mathrm{SQ}=$ Service quality, $\mathrm{CRM}=$ Customer Relationship Management

The third step involved regression analysis with service quality as a predictor of customer satisfaction. The results are depicted in Tables 4 (a-c).

\section{Table 4 (a): Model Summary}

\begin{tabular}{|l|l|l|l|l|}
\hline Model & R & R Square & Adjusted $\mathrm{R}^{2}$ & Std. Error of Estimate \\
\hline 1 & $.848^{\mathrm{a}}$ & .719 & .719 & .38276 \\
\hline
\end{tabular}

a. Predictors: (Constant), Service Quality

Source: Survey Data (2017)

Table 4 (b): ANOVA

\begin{tabular}{|l|l|l|l|l|l|l|}
\hline \multicolumn{2}{|l|}{ Model } & $\begin{array}{l}\text { Sum of } \\
\text { Squares }\end{array}$ & Df & Mean Square & F & Sig. \\
\hline \multirow{2}{*}{1} & Regression & 122.429 & 1 & 122.429 & 835.680 & $.000^{\text {a }}$ \\
\cline { 2 - 7 } & Residual & 47.760 & 326 & .147 & & \\
\cline { 2 - 6 } & Total & 170.189 & 327 & & & \\
\hline
\end{tabular} $\begin{aligned} & \text { a. Predictors: (Constant), Service Quality } \\
& \text { b. Dependent Variable: Customer Satisfaction }\end{aligned}$

Source: Survey Data (2017)

Table 4 (c): Regression Coefficients

\begin{tabular}{|c|c|c|c|c|c|}
\hline \multirow[b]{2}{*}{ Model } & \multicolumn{2}{|c|}{ Unstandardized Coefficients } & \multirow{2}{*}{$\begin{array}{l}\text { Standardized Coefficients } \\
\text { Beta }\end{array}$} & \multirow[b]{2}{*}{$\mathrm{T}$} & \multirow[b]{2}{*}{ Sig. } \\
\hline & $\mathrm{B}$ & Std. Error & & & \\
\hline $\begin{array}{ll}1 & \text { (Constant) } \\
& \text { Service }\end{array}$ & $\begin{array}{l}.041 \\
.913\end{array}$ & $\begin{array}{l}.117 \\
.032\end{array}$ & .848 & $\begin{array}{l}.356 \\
28.908\end{array}$ & $\begin{array}{l}.722 \\
.000\end{array}$ \\
\hline
\end{tabular}

a. Dependent Variable: Customer Satisfaction

Source: Survey Data (2017)

In the $4^{\text {th }}$ step, regression analysis was conducted with CRM and service quality predicting the outcome of customer satisfaction. The results are depicted in Table $5(\mathrm{a}-\mathrm{c})$. 
Table 5(a): Model Summary

\begin{tabular}{|l|l|l|l|l|}
\hline Model & & $\mathrm{R}^{2}$ & $\begin{array}{l}\text { Adjusted } \\
\mathrm{R}^{2}\end{array}$ & $\begin{array}{l}\text { Std. Error } \\
\text { Estimate }\end{array}$ \\
\hline 1 & $.852^{\mathrm{a}}$ & .725 & .724 & .37919 \\
\hline
\end{tabular}

a. Predictors: (Constant), Service Quality, CRM

Source: Survey Data (2017)

Table 5(b): ANOVA

\begin{tabular}{|l|l|l|l|l|l|l|}
\hline \multicolumn{2}{|l|}{ Model } & Sum of Squares & Df & Mean Square & F & Sig. \\
\hline \multirow{3}{*}{1} & Regression & 123.460 & 2 & 61.730 & 429.327 & $.000^{\mathrm{a}}$ \\
\cline { 2 - 7 } & Residual & 46.729 & 325 & .144 & & \\
\cline { 2 - 5 } & Total Predictors: (Constant), & 327 & & \\
\hline $\begin{array}{l}\text { a. } \\
\text { b. Dependent Variable: Customer Satisfaction }\end{array}$ \\
\hline
\end{tabular}

Source: Survey Data (2017)

Table 5(c): Regression Coefficients

\begin{tabular}{|c|c|c|c|c|c|c|}
\hline \multicolumn{2}{|c|}{ Model } & \multicolumn{2}{|c|}{ Unstandardized Coefficients } & \multirow{2}{*}{$\begin{array}{l}\text { Standardized } \\
\text { Coefficients } \\
\text { Beta }\end{array}$} & \multirow[t]{2}{*}{$\mathrm{t}$} & \multirow[t]{2}{*}{ Sig. } \\
\hline & & B & Std. Error & & & \\
\hline \multirow[t]{3}{*}{1} & (Constant) & -.036 & .119 & & -.300 & .764 \\
\hline & CRM & .145 & .054 & .136 & 2.677 & .008 \\
\hline & $\begin{array}{l}\text { Service } \\
\text { Quality }\end{array}$ & .794 & .055 & .737 & 14.562 & .000 \\
\hline
\end{tabular}

Source: Survey Data (2017)

Table 5(a) shows an adjusted $\mathrm{R}^{2}=0.724$. This means that $72.4 \%$ of the changes in customer satisfaction can be explained by the predictor variables (CRM and service quality). The results in Table 5(b) indicate an Fstatistic $=429.327$ and $\mathrm{P}$-value $=0.000<0.05$. This shows that $\mathrm{CRM}$ and service quality had a significant effect on customer satisfaction.

Regression results in Table 5 (c) show regression coefficients of CRM and service quality of 0.145 which implies that keeping other factors constant, a unit change in CRM, increases customer satisfaction by a factor of 0.145. Similarly, a regression coefficient of 0.794 implies that keeping other factors constant a unit increase in service quality increases customer satisfaction by a factor of 0.794 . Therefore, the coefficients for both predictor variables were statistically significant and support partial mediation. The results indicate a statistically significant mediating effect of service quality on the relationship between CRM and customer satisfaction. Based on the findings in Table 5 (a-c), the following model for predicting customer satisfaction was developed;

$\mathrm{CS}=-0.036+0.145 \mathrm{CRM}+0.794 \mathrm{SQ}+0.119+\varepsilon \quad$ Where; $\mathrm{CS}=$ Customer satisfaction, $\mathrm{CRM}=$ Customer Relationship Management, $\mathrm{SQ}=$ Service Quality, $\varepsilon=$ Error term

\subsection{Conclusion}

Regression analysis of the three independent variables indicated that an increase in each of them resulted in increase in account holder satisfaction. The study concluded that service quality had a statistically significant mediating effect on the relationship between CRM and account holder satisfaction with commercial banking services. Tangibility which refers to appearance of physical facilities, employees and equipment had the greatest effect on account holders' satisfaction whereas responsiveness had the least rating. Therefore, commercial banks need to be responsive to customer needs and complaints regarding service quality. Subsequently, the study elucidates the need for commercial banks to engage in continuous service improvement and differentiation as well as development of CRM strategies that enhance service quality.

\subsection{Contribution of the Study to Knowledge}

The findings on the mediating effect of service quality revealed a positive and significant relationship between the variables. This brings out new constructs that define these variables and their interrelationships. This study therefore contributes to the need for empirical research on CRM, service quality and satisfaction of commercial banks account holders in Kenya. In addition, the study provides a conceptual framework that serves as a tool for predicting the relationship between CRM and satisfaction of customers in the banking sector. The study also addresses the gap in methodology in CRM and satisfaction in banking literature by applying the mixed methodology design which employs quantitative methods that contribute to a comprehensive study. This provides researchers with an appropriate framework that incorporates quantitative methods in CRM and satisfaction studies in the banking sector. 
The study further contributes to new knowledge by conceptualizing variables previously studied differently such as CRM, service quality and customer satisfaction. It validates the mediating role of service quality on the relationship between CRM and satisfaction of account holders in commercial banks. Therefore, the study identifies some of the knowledge gaps cited in the literature and contributes to the frontiers of knowledge related to CRM and satisfaction of account holders' in the banking sector. Specifically, the study measured customer satisfaction in terms of positive experience with bank customers, preference for banks products and services, image of the bank and its accessibility that reveal the feelings of customers as opposed to customer loyalty, repeat purchase and advocacy measures used in previous studies to assess the behavior of customers. Finally, this study makes significant contribution to the advancement of academic knowledge and theory on CRM and customer satisfaction in the context of the financial sector in an African setting.

\subsection{Recommendations for Policy Implications}

The results of this study have significant managerial implications to commercial bank managers that develop and implement CRM strategies. With regard to the study findings, commercial bank managers should enhance their CRM strategies in order to provide quality services that satisfy customers. Consequently the Central Bank of Kenya and the government should develop policies relating to CRM, service quality and customer satisfaction in order to protect account holders.

\subsection{Acknowledgement}

The author is grateful to Dr.Samuel Maina and Dr. Linda Kimencu for their insights, devotion, scholarly critique, guidance and support towards the completion of this study.

\section{REFERENCES}

Al-Azzam, M. \& Fattah. A (2015).The impact of service quality dimensions on customer Satisfaction: A field study of Arab banks in Irbid city of Jordan. European Journal of Business \& Management, 7(15).

Anatastiadou, K. \& Jamal. A.(2009). Investigating the effects of service quality dimensions and expertise on loyalty. European Journal of Marketing, 43 (3/4), 398-420.

Baron, R.M.,\& Kenny, D.A. ( 1986). The moderator - mediator variable distinction in social psychological Rresearcal: conceptual, strategic and statistical considerations. Journal of Personality and Social Psychology, $51,1173-1182$.

Battisti, F., Nicollini,G.\& Salini,S. (2011). The RASCH Model to measure service quality. Journal of Services Marketing, 3(3), 58-80.

Borg, W. R., \& Gall, M. D. (1989). Education Research: An Introduction. New York: Longman Publisher.

Chan, J. \& Ahmad, F. (2013). Factors affecting customer satisfaction in retail banking: An empirical study. International Journal of Business and Management Inventions (2), 55-62.

Cooper, D. R. \& Schindler, P. S. (2003). Business Research Methods, $8^{\text {th }}$ Ed. New Delhi: Tata McGraw-Hill Publishing Company Ltd.

Cronbach, M. and Hedge, R. (2001). Construct validity in psychological tests. Psychological Bulletin, 52, 281 302.

Cronin, J. J. and Taylor, S. A. (1992). Measuring service quality: A re-examination and extension. Journal of Marketing, 56 (3), $55-68$.

Deming,W.E. (1986). Out of the crisis. Boston. MIT Centre for Advanced Engineering Study.

Djajanto, L., Nimran,U., Kumadji, S. \& Kertahadi (2014). The effect of self service technology,service quality and relationship marketing on customer satisfaction and customer loyalty. Journal of Business Management, $16(1), 39-50$.

Fasih, M. \& Khan, M.M. (2014). Impact of service quality on customer satisfaction and customer loyalty: Evidence from banking sector. Pakistan Journal of Commerce \& Social Sciences, 8(2), 331-354.

Field, A. P. (2009). Discovering Statistics Using SPSS (2 ${ }^{\text {nd }}$ Ed.) London: Sage.

Fornell, C. (1992). A national customer satisfaction barometer: The Swedish experience. Journal of Marketing, $56,6-21$.

Gay, L.R .(1981). Educational Research: Competencies for Analysis and Application. Columbus, Charles E. Merrill Publications.

Giese, J.L. \& Cote, J.A. (2000). Defining consumer satisfaction. Academy of Marketing Science Review, 20 (1) 120.

Godson, M. (2009). Relationship marketing. Oxford University Press Inc., New York

Gronroos, C. (2002). Understanding the customer base of service providers. An examination of the difference between switchers and stayers. Journal of Marketing, 60, 21-49.

Hansemark, O.C. \& Abinson, M. (2004). Customer satisfaction and retention: The experiences of individual with employees. Managing Service Quality, 14, 1. 
Kheng, L. L., Mohamed O., Ramayah, T. \& Mosahab, R. (2010). The impact of service quality on customer satisfaction: A study of banks in Penang, Malaysia. International Journal of Marketing Studies, 2, 2.

Kothari, C. R. (2004). Research Methodology: Methods and techniques. New Delhi: New Age International.

Kotler, P. \& Keller, K.L. (2006). Marketing Management $\left(12^{\text {th }}\right.$ ed.). Upper Saddle River, NJ: Pearson Prentice Hall.

KPMG(2013). Africa banking industry customer satisfaction survey. Amstelveen, Netherlands.

Mihelis, G. Grigoroudis, E. Siskos, Y. Politis,Y. \& Malanrakis, Y. (1998). Measuring Customer satisfaction in the private bank sector. Athens, Greece.

Malhotra, N., Hall, J., Shaw, M. \& Oppenheim, P. (2002). Marketing Research: An Applied Orientation. PrenticeHall:Sydney.

Murugiah, L. \& Akgam, H. (2015). Study of customer satisfaction in the banking sector in Libya. Journal of Economics, Business and Management, 3,7.

Narver, J. \& Slater, S.F.(1990).The effect of market orientation on business profitability. Journal of Marketing, 54, 20-35.

Parasuraman, A., Berry, L.L.\& Zeithaml,V.A(1985). A conceptual model of service quality and implications for future research. Journal of Marketing 49, 41-50.

Parasuraman, A., Berry, L. L. \& Zeithaml, V. A. (1988). SERVQUAL: A multi-item scale for measuring consumer perceptions of service quality. Journal of Retailing, 64, $12-40$.

Parvatiyar, A. \& Sheth, J. N. (2002). Customer relationship management: Emerging practice, process and discipline. Journal of Economics and Social Research, 3(2).

Peppers, D., Rogers, M. \& Dorf, B. (1999). Is your company ready for one-to-one marketing? Harvard Business Review, $151-160$.

Robledo M. A. (2001). Measuring \& managing service quality: Integrating customer expectations. Journal of Managing Service Quality, 2 (1), 22 - 31.

Rogelberg, S. \& Santon, J. (2007).Understanding \& dealing with organizational survey non-response. Organizational Research Methods, 10, 195-209.

Rostami, R.A., Valmohammadi, C. \& Yousefpoor, J. (2014). The relationship between customer satisfaction and customer relationship management; a case study of Ghavamin Bank. Industrial and Commercial Training, 46(4), 220-227.

Roy, S. K. (2014). Factors Affecting CRM practices in commercial banks. A case of selected banks in India. International Journal of Current Research, 6 (11), 1034 - 1035.

Roy, S. K. \& Ganguli, S. (2011). Generic technology-based service quality dimensions in banking. International Journal of Bank Marketing, 29 (2), 163 - 189.

Sadek, H. \& Tantawi, P. (2009). Measuring customer relationship management and its relationship with satisfaction in the Egyptian banking sector. Arab Academy for Science, Technology and Maritime Transport, Egypt.

Sahieh, C.J, (2006). The relationship between service quality and customer satisfaction. The Example of CJCU Library, 27 (1) 193-209.

Saunders, M. N., Lewis P. \& Thornhill, A., (2009). Research methods for business students. Pearson Education, India.

Sin, L.Y.M., Tse, A.C.B. \& Yim, F. H.K. (2005). CRM: Conceptualization and scale development. European Journal of Marketing, 39(11/12), 1264 - 1290.

Sultan, P. \& Wong, H. (2010). Performance based service quality model: An empirical study of Japanese universities. Quality Assuarance in Education, 18(2), 126-143.

Sureshschandar, G.S., Rajendran, C., \& Anatharaman, R.N. (2002). Determinants of customer perceived service quality. A confirmatory factor analysis approach. Journal of Service Marketing, 16 (1), 9-34.

Thurkar, R., Summey, J. H. \& Balasubramanian, S. K. (2006). CRM as a strategy: Avoiding the pitfalls of tactics. The Marketing Management Journal, 16 (2), 147 - 154.

U1 Haq, I. Rammay, M.I., Urehman, M. \& Jam, F. (2010). Big five personality and perceived customer relationship management. Research Journal of International Studies, (15).

Yamane, T., (1967). Statistics: An Introductory Analysis (2 ${ }^{\text {nd }}$ ed.). New York: Harper and Row.

Zeithaml, V.A. (1988). Consumer perception of price, quality and value: A means-end model and synthesis of evidence. The Journal of Marketing, 52 (3), 2-22.

Zeithaml, V.A., Bitner, M.J., \& Gremler, D.D. (2006). Service Marketing: Integrating Customer Focus Across the Firm ( $4^{\text {th }}$ Ed). New York: McGraw Hill International. 